\title{
SCREENING OF SOME MEDICINAL PLANTS USED IN NEPALESE TRADITIONAL MEDICINE AGAINST ENTERIC BACTERIA
}

\author{
Anup Muni Bajracharya*, Kayo Devi Yami**, Tista Prasai**, Shital Raj Basnyat* and Binod Lekhak* \\ *Central Department of Microbiology, Tribhuvan University, Kirtipur, Kathmandu, Nepal. \\ **Nepal Academy of Science and Technology, Khumaltar, Kathmandu, Nepal.
}

\begin{abstract}
Antibacterial properties of ethanolic extracts of 8 medicinal plants used in Nepal to treat gastrointestinal disorders were tested against ten different species of enteropathogenic bacteria: Escherichia coli, Klebsiella spp, Citrobacter spp, Enterobacter spp, Salmonella typhi, Salmonella paratyphi, Shigella spp, Proteus vulgaris, Proteus mirabilis and Pseudomonas spp. Among the selected medicinal plants: Punica granatum, Woodfordia fruticosa, Psidium guajava and Syzygium cumini were found effective against all enteric bacteria whereas Mimosa pudica, Acorus calamus, Aegle marmelos and Anethum sowa were found ineffective against all. The minimum bactericidal concentration (MBC) of these plant extracts found against Salmonella typhi, Salmonella paratyphi, Proteus mirabilis and Proteus vulgaris were lower (0.39-25mg/ml) so are more susceptible whereas the plants showed lethal effect against Pseudomonas spp, Citrobacter spp, Enterobacter spp, E. coli, Shigella spp. and Klebsiella spp. at MBC value of around 25-50mg/ml.
\end{abstract}

Key words: Medicinal plants; Antibacterial activity; Plant extracts.

\section{INTRODUCTION}

Many efforts have been made to discover new antimicrobial compounds from various kinds of sources such as microorganisms, animals, and plants. One of such resources is folk medicines. Systematic screening of them may result in the discovery of novel effective compounds (Tomoko et al, 2002). Medicinal plants have been used as traditional treatments for numerous human diseases for thousands of years. Diarrhoeal diseases continue to be a major cause of morbidity and mortality throughout the world. Thus, their treatment by using medicinal plant is an important public health issue. Medicinal properties of plants are due to the active chemical constituents present in different parts of the plant (Mitscher et al, 1980).

Even though pharmacological industries have produced a number of new antibiotics in the last three decades, resistance to these drugs by microorganisms has increased (Nascimento et al, 2000).The increasing prevalence of multidrug resistant strains of bacteria and the recent appearance of strains with reduced susceptibility to antibiotics raises the specter of untreatable bacterial infections and adds urgency to the search for new infection-fighting strategies (Sieradzki et al, 1999). According to WHO, medicinal plants would be the best source to obtain a variety of drugs. Contrary to the synthetic drugs, antimicrobials of plant origin are not associated with many side effects and have an enormous therapeutic potential to heal many infectious diseases (Iwu et al, 1999).
In Nepalese traditional medicine, there is a rich local ethnobotanical bibliography describing the species most frequently used by the population to cure gastrointestinal, respiratory, urinary and skin infections (HMG, 1993; Rajbhandari, 2001). However, there is a lack of experimental scientific studies confirming the possible antibiotic properties of a great number of these remedies. In vitro antimicrobial screening methods provide the required preliminary observations to select, among the crude plant products, those with potentially useful properties for further chemical and pharmacological studies.

The eight plant species here selected are reported to be used for the treatment of diarrhea, dysentery, cholera, fever and other gastrointestinal disorders classified under Medicinal plants of Nepal (HMG, 1993) and Ethnobotany of Nepal (Rajbhandari, 2001)

Based on local use for common diseases and ethnobotanical knowledge, an attempt to assess the antibacterial property of medicinal plants was made in this study.

\section{MATERIALS AND METHODS}

\subsection{Plant material}

Different parts of selected medicinal plants were collected from different parts of Kathmandu Valley and were identified according to various literatures like Medicinal plants of Nepal by HMG/N (1993), Ethnobotany of Nepal (Rajbhandari, 2001) and including other pertinent taxonomic literature. The list of

Author for Correspondence: Ms. Tista Prasai , Nepal Academy of Science and Technology Khumaltar, Kathmandu, Nepal. Email: tistaprasai@yahoo.com 


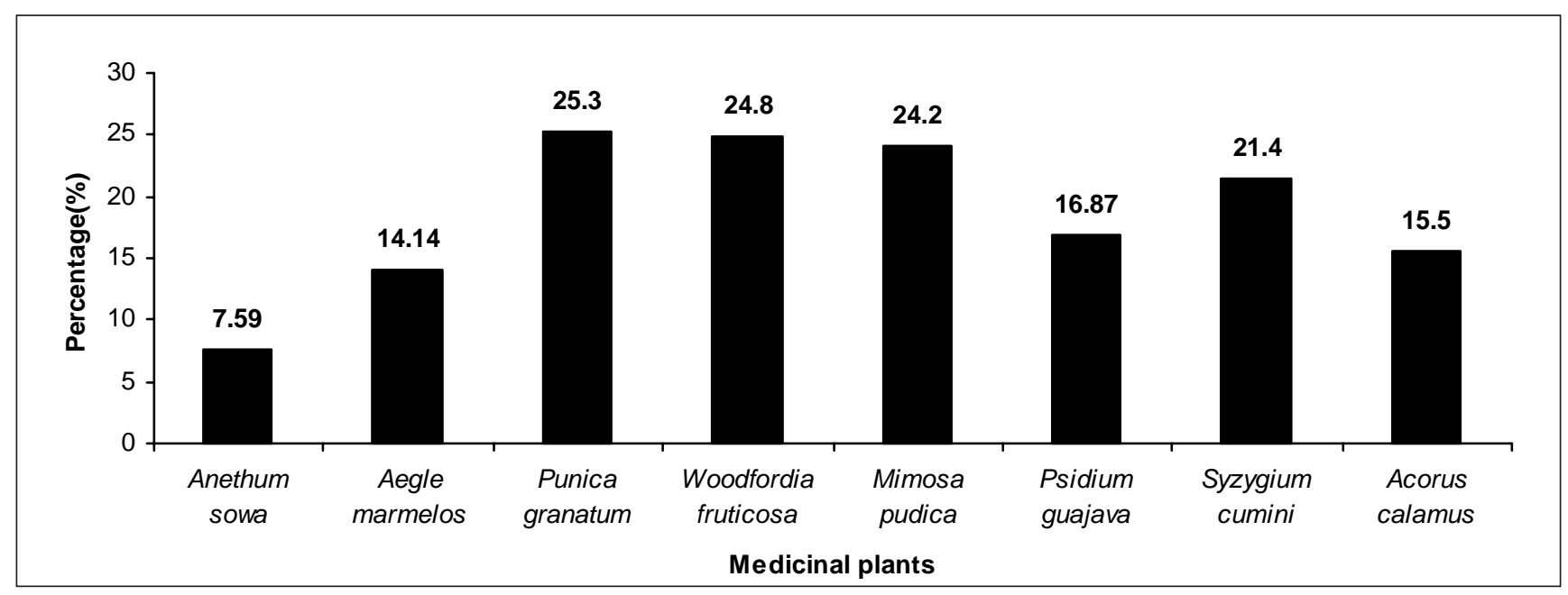

Figure 1: Percentage yields of ethanol crude extracts of medicinal plants

medicinal plants, their corresponding part used in this study, month of sample collection and location/place of the sample plants was given in the Table 1.

\subsection{Preparation of extracts}

Plant materials were dried in the dark at room temperature, powdered and extracted by soxhlet extraction method using ethanol as solvent. Afterwards, the solvent was distilled under reduced pressure in a rotary vacuum evaporator until the extracts became dry. The percentage yield for each extract was determined and the crude extract was then transferred in a bottle by sterile spatula. One-gram crude ethanol extract from each medicinal plant was mixed with $9 \mathrm{ml}$ of sterile distilled water in test tube \& vortexed to make homogenous mixture/ solution/suspension of $1 \mathrm{~g} / 10 \mathrm{ml}$ i.e. $100 \mathrm{mg} / \mathrm{ml}$ working suspension or solution and stored in a refrigerator $\left(2-8^{\circ} \mathrm{C}\right)$.

\subsection{Microorganisms}

The strains of microorganisms employed were Escherichia coli, Klebsiella spp, Citrobacter spp, Enterobacter spp, Salmonella typhi, Salmonella paratyphi, Shigella spp, Proteus vulgaris, Proteus mirabilis and Pseudomonas spp. All the microorganisms were maintained at $4{ }^{\circ} \mathrm{C}$ on nutrient agar slants.

\subsection{Antimicrobial activity}

The crude extract of medicinal plant was screened for its antibacterial activity i.e. determination of zone of inhibition against tested organism by agar well diffusion method as given by Dingle et al (1953). The crude extracts which showed antibacterial activity were subjected to two-fold serial dilution method to determine minimum bactericidal concentration (MBC). The fresh bacterial culture comparable with turbidity standard was prepared and swabbed on the surface of MullerHinton agar plates. Wells of diameter $6 \mathrm{~mm}$ were made in the inoculated media plate. To evaluate the efficiency of the methodology, $50 \mu$ l of each working suspension of extract was transferred into the well and the plates were incubated at $37^{\circ} \mathrm{C}$ for 24 hours. After this period, it was possible to observe zone of inhibition. Overall, cultured bacteria with halos greater than $8 \mathrm{~mm}$ were considered susceptible to the tested extract. The extracts which showed antibacterial activity were subjected to two-fold serial dilution method to determine MBC.

\section{RESULT AND DISCUSSION}

The percentage yields of the ethanol crude extract of medicinal plants as obtained by soxhlet extraction process are shown in the figure 1 . The amount of crude extracts varied among the medicinal plants. Punica granatum gave the highest yield (25.30\%) and lowest yield was obtained from Anethum sowa (7.59\%).

The data pertaining to the antibacterial potential of the plant extracts are presented in Table 2 . In addition inhibition zone formed by extracts and MBC value against enteric bacteria are listed in Table 3. It was revealed from the result that each medicinal plant shows different degree of inhibition against different microorganisms. The diameter of zone of inhibition produced depends on several factors broadly classified as extrinsic and intrinsic parameters. The extrinsic parameters like $\mathrm{pH}$ of the medium, period and temperature of incubation, volume of the well, concentration of plant extracts and size of inoculums can be fixed and standardized during experiment, hence no error results due to extrinsic factors. However, intrinsic factors such as nature of medicinal plants including its components, solubility and diffusing property are predetermined. Due to variable diffusibility, the antibacterial with very high potency may not demonstrate a ZOI commensurate to its efficacy (Prasai et al, 2004).

The maximum zone of inhibition was observed in case of Proteus mirabilis $(31 \mathrm{~mm})$ due to the action of Syzygium cumini and minimum was against Pseudomonas spp. (10mm) shown by Psidium guajava. The results revealed variability in the bactericidal concentrations of each extract for given bacteria. The minimum bactericidal concentration (MBC) of these plant extracts found against Salmonella typhi, Salmonella paratyphi, Proteus mirabilis and Proteus vulgaris were lower $(0.39-25 \mathrm{mg} / \mathrm{ml})$ so are more susceptible whereas the plants showed lethal effect against Pseudomonas 
Table 1: List of medicinal plants used in antimicrobial assay.

\begin{tabular}{|l|l|l|l|l|l|l|}
\hline S.N & Local Name & \multicolumn{1}{|c|}{ Botanical Name } & Family & Part used & $\begin{array}{c}\text { Month of } \\
\text { collection }\end{array}$ & \multicolumn{1}{|c|}{ Location /District } \\
\hline 1 & Saunp & Anethum sowa & Umbelliferae & seeds & April & Market /Kathmandu \\
\hline 2 & Bel & Aegle marmelos & Rutaceae & Fruit & May & Rudrapipal/Baglung \\
\hline 3 & Anar & Punica granatum & Punicaceae & rind of fruit & June & Market /Kathmandu \\
\hline 4 & Dhanyero & Woodfordia fruticosa & Lythraceae & leaves & May & Godawari/Lalitpur \\
\hline 5 & Lajjawati & Mimosa pudica & Febaceae & leaves & June & Khumaltar/Lalitpur \\
\hline 6 & Guava & Psidium guajava & Myrtaceae & leaves & June & Thimi/Bhaktapur \\
\hline 7 & Jamun & Syzygium cumini & Myrtaceae & leaves & June & Chyashal/Lalitpur \\
\hline 8 & Bojho & Acorus calamus & Araceae & rhizome & May & Godawari/Lalitpur \\
\hline
\end{tabular}

Table 2: Antibacterial activity caused by plant extracts through agar diffusion method.

\begin{tabular}{|c|c|c|c|c|c|c|c|c|c|c|c|}
\hline SN & Medicinal Plants & $\begin{array}{l}\text { E. } \\
\text { coli }\end{array}$ & $\begin{array}{l}\text { Klebsiella } \\
\text { spp. }\end{array}$ & $\begin{array}{l}\text { Citrobact } \\
\text { er spp. }\end{array}$ & $\begin{array}{l}\text { Enterobacter } \\
\text { spp. }\end{array}$ & $\begin{array}{l}\text { Salmonel } \\
\text { la typhii }\end{array}$ & $\begin{array}{l}\text { Salmonella } \\
\text { paratyphi }\end{array}$ & $\begin{array}{l}\text { Shigella } \\
\text { spp. }\end{array}$ & $\begin{array}{l}\text { Proteus } \\
\text { vulgaris }\end{array}$ & $\begin{array}{l}\text { Proteus } \\
\text { mirabilis }\end{array}$ & $\begin{array}{l}\text { Pseudo } \\
\text { monas } \\
\text { spp. }\end{array}$ \\
\hline 1 & Anethum sowa & - & - & - & - & - & - & - & - & - & - \\
\hline 2 & Aegle marmelos & - & - & - & - & - & - & - & - & - & - \\
\hline 3 & Punica granatum & + & + & + & + & + & + & + & + & + & + \\
\hline 4 & $\begin{array}{l}\text { Woodfordia } \\
\text { fruticosa }\end{array}$ & + & + & + & + & + & + & + & + & + & + \\
\hline 5 & Mimosa pudica & - & - & - & - & - & - & - & - & - & - \\
\hline 6 & Psidium guajava & + & + & + & + & + & + & + & + & + & + \\
\hline 7 & Syzygium cumini & + & + & + & + & + & + & + & + & + & + \\
\hline 8 & Acorus calamus & - & - & - & - & - & - & - & - & - & - \\
\hline
\end{tabular}

(+) Susceptibility (Inhibition zone $>8 \mathrm{~mm}$ )

(-) Absence of susceptibility

Table 3: Antimicrobial activity of crude ethanol extracts.

\begin{tabular}{|c|c|c|c|c|c|c|c|c|c|}
\hline \multirow{3}{*}{ SN } & \multirow{3}{*}{ Test organisms } & \multicolumn{8}{|c|}{ Antimicrobial activity } \\
\hline & & \multicolumn{2}{|c|}{ Punica granatum } & \multicolumn{2}{|c|}{ Psidium guajava } & \multicolumn{2}{|c|}{ Syzygium cumini } & \multicolumn{2}{|c|}{ Woodfordia fruticosa } \\
\hline & & $\begin{array}{c}\mathrm{ZOI} \\
(\mathrm{mm})\end{array}$ & $\begin{array}{c}\text { MBC } \\
(\mathrm{mg} / \mathrm{ml})\end{array}$ & $\begin{array}{c}\text { ZOI } \\
(\mathrm{mm})\end{array}$ & $\begin{array}{c}\text { MBC } \\
(\mathrm{mg} / \mathrm{ml})\end{array}$ & $\begin{array}{c}\mathrm{ZOI} \\
(\mathrm{mm})\end{array}$ & $\begin{array}{c}\text { MBC } \\
(\mathrm{mg} / \mathrm{ml})\end{array}$ & $\begin{array}{c}\mathrm{ZOI} \\
(\mathrm{mm})\end{array}$ & $\begin{array}{c}\text { MBC } \\
(\mathrm{mg} / \mathrm{ml})\end{array}$ \\
\hline 1 & E. coli & 21 & 50 & 16 & 50 & 21 & 50 & 16 & 50 \\
\hline 2 & Klebsiella spp. & 27 & 6.25 & 25.5 & 50 & 25 & 50 & 20 & 50 \\
\hline 3 & Citrobacter spp. & 25 & 25 & 16 & 50 & 20 & 25 & 20 & 50 \\
\hline 4 & Enterobacter spp. & 23 & 50 & 19.5 & 50 & 22.5 & 50 & 18.5 & 50 \\
\hline 5 & Salmonella typhii & 19 & 3.12 & 13 & 6.25 & 10.5 & 3.12 & 26.5 & 1.56 \\
\hline 6 & Salmonella paratyphi & 25 & 1.56 & 20 & 3.12 & 20 & 0.39 & 15 & 25 \\
\hline 7 & Shigella spp. & 23 & 50 & 14 & 50 & 19.5 & 50 & 15 & 25 \\
\hline 8 & Proteus vulgaris & 16 & 6.25 & 15 & 25 & 18 & 1.56 & 22 & 1.56 \\
\hline 9 & Proteus mirabilis & 30 & 12.5 & 24 & 12.5 & 31 & 12.5 & 23 & 25 \\
\hline 10 & Pseudomonas spp. & 11 & 50 & 10 & 50 & 11.5 & 25 & 15 & 50 \\
\hline
\end{tabular}

spp, Citrobacter spp, Enterobacter spp, E. coli, Shigella spp. and Klebsiella spp. at MBC value of around 25-50mg/ $\mathrm{ml}$ The zone of inhibition (ZOI) and minimum bactericidal concentration (MBC) are two different attributes and there is absence of linear relationship between ZOI and MBC values.

As can be seen from Table 2, only four of plant extracts viz. Punica granatum, Woodfordia fruticosa, Psidium guajava and Syzygium cumini showed an antimicrobial effect against all ten enteric bacteria. Antibacterial activity due to Punica granatum was previously reported. (Perez and Anesini, 1994; Bhatta, 1998; Rani and Khullar, 2003; Alanis et al, 2005) Similarly, activity due to Psidium guajava (Ahmad \& Beg, 2001; Holetz et al 2002), Syzygium cumini (Nascimento et al, 2000; Baidya, 2001) and Woodfordia fruticosa (Timsina, 2003) was also reported.

Considering that in this study only crude ethanolic extracts 
were employed and that Gram-negative organisms are in general terms more resistant than Gram positive ones to antimicrobial agents, we considered a strong response to exist when the extracts produced an effect at concentrations of $25 \mathrm{mg} / \mathrm{ml}$ or below for enteric bacteria. Thus Salmonella typhi, Salmonella paratyphi, Proteus mirabilis and Proteus vulgaris are more susceptible having MBC value $(0.39-25 \mathrm{mg} /$ $\mathrm{ml}$ ) whereas the plants showed lethal effect against Pseudomonas spp, Citrobacter spp, Enterobacter spp, E. coli, Shigella spp. and Klebsiella spp. at MBC value of around $25-50 \mathrm{mg} / \mathrm{ml}$.

The results obtained indicate the existence of antimicrobial compounds in the crude ethanolic extracts of these plants and show a good correlation between the reported uses of these plants in Medicinal plants of Nepal against different diseases and the experimental data of such extracts toward the most common pathogens. The cidal activities of medicinal plants like Punica granatum, Woodfordia fruticosa, Psidium guajava and Syzygium cumini are due to the active constituents present in them. The compounds like ellagitannins and alkaloids in the rind of fruit Punica granatum, flavonoids and tannins in leaf of Syzygium cumini; comarins, essential oils, flavonoids, triterpenes and ellagitannins in leaf of Psidium guajava and tannins, flavonoids, anthraquinone glycosides and polyphenols in Woodfordia fruticosa have been reported (Nascimento et al 2000). Other four plants namely Mimosa pudica, Acorus calamus, Aegle marmelos and Anethum sowa, though were selected on the basis of their use in common diseases like diarrhea, dysentery, fever etc, they didn't show antimicrobial activity against enteric bacteria isolates. This can be due to the inability of water to dissolve the active components of alcoholic extracts of the plants during preparation of working solution or microorganisms used are not susceptible to these extracts.

The results of the present study provide a scientific validation for the popular use of the medicinal plants studied and serve as a guide which may help in selection of plants with antimicrobial activities for further phytochemical work on the isolation and the identification of the active compounds.

\section{CONCLUSIONS}

Result express that plant extracts have great potential as antimicrobial compounds against microorganisms. Thus, they can be used in the treatment of infectious diseases. Punica granatum, Woodfordia fruticosa, Psidium guajava and Syzygium cumini extracts possess a broad spectrum of activity against a panel of bacteria responsible for the most common bacterial diseases. These promissory extracts open the possibility of finding new clinically effective antibacterial compounds.

\section{ACKNOWLEDGEMENTS}

Acknowledgements are due to Nepal Academy of Science and Technology, Khumaltar for the laboratory facilities and instruments provided by them.

\section{REFERENCE}

Ahmad, I. and Beg, A.Z. 2001. Antimicrobial and phytochemical studies on 45 Indian medicinal plants against multi-drug resistant human pathogens. J Ethnopharmacol. 74: 113-23.

Alanis, A.D., Calzada, F., Cervanter, J.A., Torres, J. and Ceballos, G.M. 2005. Antibacterial properties of some plants used in Mexican traditional medicine for the treatment of gastrointestinal disorders. J Ethnopharmacol. 100:153-7.

Anesini, C. and Perez, C. 1993. Screening of plants used in Argentine folk medicine for antimicrobial activity. J Ethnopharmacol. 2:119-28.

Baidya, M.R. 2001. Screening and Evaluation of in vitro Antimicrobial Activity of Medicinal Plants of Nepal. M.Sc.Thesis, Central Department of Microbiology, Tribhuvan University, Kirtipur, Kathmandu.

Bhatta, L. 1998. Study of Antimicrobial Properties of Punica granatum. M.Sc. Thesis, Central Department of Microbiology, Tribhuvan University, Kirtipur, Kathmandu.

Dingle, J., Red, W.W. and Solomons, G.L. 1953. The Enzymatic Degradation of Pectin and Other Polysaccharides II Application of Cup Assay Method to the Estimation of Enzyme. Journal of Science, Food and Agriculture. 4:149-53.

HMG/N. 1993. Medicinal Plants of Nepal. Ministry of Forest and Soil Conservation, Department of Plant Resources. Kathmandu, Nepal.

Holetz, F.B., Pessini, G.L., Sanches, N.R., Cortez, D.A.G., Nakamura, C.V. and Dias Filho, B.P. 2002. Screening of some plants used in the Brazilian folk medicine for the treatment of infectious diseases. Mem Inst Oswaldo Cruz. 97:1027-31.

Mitscher, L.A., Park, Y.H. and Clark, D. 1980. Antimicrobial agents from higher plants, antimicrobial isoflavonoids and related substances from Glycyrhiza glabra. Journal of Natural Products. 43:259-69.

Nascimentom G.G.F., Locatelli, J., Freitas, P.C. and Silva, G.L. 2000. Antibacterial activity of plant extracts and phytochemicals on antibiotic resistant bacteria. Brazilian journal of microbiology. 31:247-56.

Perez, C. and Anesini, C. 1994. In vitro antibacterial activity of Argentine folk medicinal plants against Salmonella typhi. $J$ Ethnopharmaco. 44:41-6.

Prasai, T., Lekhak, B. and Baral, M.P. 2004. Antibacterial property of medicinal plants against gram negative bacteria isolated from water. Proceedings of IV National Conference on Science and Technology. 2:410-15.

Rajbhandari, R.K. 2001. Medicinal Plants. In: Ethnobotany of Nepal. Ethnobotanical Society of Nepal, pp 98-134.

Rani, P. and Khullar, N. 2003. Antimicrobial evaluation of some medicinal plants for their anti-enteric potential against multidrug resistant Salmonella typhi. Phytotherapy Research 18(8):670-673.

Sieradzki, K., Roberts, R.B., Haber, S.W. and Tomasz, A. 1999. The development of vancomycin resistance in a patient with methicillin-resistant Staphylococcus aureus infection. N. Engl. J. Med., 340: 517-523.

Timsina, G. 2003. Evaluation of antimicrobial activities of some medicinal plants used in traditional medicine in Nepal. M.Sc Thesis, Central Department of Botany, Tribhuvan University, Kirtipur, Kathmandu.

Tomoko, N., Takashi, A., Hiromu, T., Yuka, I., Hiroko, M., Munekazu, I., Fujio, A. and Kazuhito, W. 2002. Antibacterial activity of extracts preparated from tropical and subtropical plants on methicillinresistant Staphylo-coccus aureus. J. Health Sci., 48: 273-76.

WHO. 1991. Antimicrobial susceptibility testing. In: Basic Laboratory Procedure in Clinical Bacteriology. World Health Organization, Geneva, pp 78-95.

WHO. 1998. Quality controls methods for medicinal plant materials. World Health Organization, Geneva. 